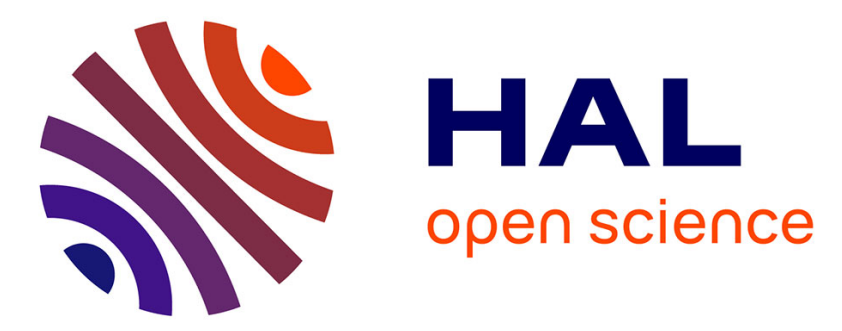

\title{
Stimulation of gonadotropin secretion and spermiation in carp by pimozide-LRH-A treatment: effects of dose and time of day
}

\author{
Roland Billard, K. Bieniarz, P. Popek, P. Epler, Bernard Breton, K.
}

Alagarswami

\section{To cite this version:}

Roland Billard, K. Bieniarz, P. Popek, P. Epler, Bernard Breton, et al.. Stimulation of gonadotropin secretion and spermiation in carp by pimozide-LRH-A treatment: effects of dose and time of day. Aquaculture, 1987, 62, pp.161-170. 10.1016/0044-8486(87)90320-6 . hal-02728154

\section{HAL Id: hal-02728154 \\ https://hal.inrae.fr/hal-02728154}

Submitted on 2 Jun 2020

HAL is a multi-disciplinary open access archive for the deposit and dissemination of scientific research documents, whether they are published or not. The documents may come from teaching and research institutions in France or abroad, or from public or private research centers.
L'archive ouverte pluridisciplinaire HAL, est destinée au dépôt et à la diffusion de documents scientifiques de niveau recherche, publiés ou non, émanant des établissements d'enseignement et de recherche français ou étrangers, des laboratoires publics ou privés.

\section{()(1)(2)}

Distributed under a Creative Commons Attribution - ShareAlikel 4.0 International 


\title{
Stimulation of Gonadotropin Secretion and Spermiation in Carp by Pimozide-LRH-A Treatment: Effects of Dose and Time of Day
}

\author{
R. BILLARD ${ }^{1}$, K. BIENIARZ ${ }^{2}$, W. POPEK ${ }^{2}$, P. EPLER ${ }^{2}$, B. BRETON ${ }^{3}$ and K. \\ ALAGARSWAMI ${ }^{4}$ \\ ${ }^{1}$ I.N.R.A., Station de Physiologie animale, 78350 Jouy-en-Josas (France) \\ ${ }^{2}$ Academy of Agriculture, Department of Ichthyobiology and Fisheries, Ambroswa 6, 30-149 \\ Krakow-Mydlniki (Poland) \\ ${ }^{3}$ I.N.R.A., Laboratoire de Physiologie des Poissons, Campus de Beaulieu, 35042 Rennes cédex \\ (France) \\ ${ }^{4}$ Central Marine Research Institute, P.B. 1912, Cochin 682018 (India)
}

(Accepted 19 August 1986)

\section{ABSTRACT}

Billard, R., Bieniarz, K., Popek, W., Epler, P., Breton, B. and Alagarswami, K., 1987. Stimulation of gonadotropin secretion and spermiation in carp by pimozide-LRH-A treatment: effects of dose and time of day. Aquaculture, 62: 161-170.

To define the optimal combination time and LRH-A (luteinizing releasing hormone analogue) administration route for inducing spermiation in carp, two experiments were carried out. In the first experiment, carp kept in raceways in running recycled water in August (at a water temperature of $15-20^{\circ} \mathrm{C}$ ) were injected intraperitoneally with pimozide (PIM) at 1 or $10 \mathrm{mg} / \mathrm{kg}$ body weight as well as with Des-Gly ${ }^{10}\left[\mathrm{D}-\right.$ Tryp $\left.^{6}\right] \mathrm{LH}-\mathrm{RH}$-ethylamide (LRH-A) at $0.1,1$ or $10 \mu \mathrm{g} / \mathrm{kg}$; these products were given $6 \mathrm{~h}$ apart. The response was evaluated by the volume of milt and the number of spermatozoa emitted and by the gonadotropin (GTH) concentration in the plasma. At doses of $0.1,1$ and $10 \mu \mathrm{g} / \mathrm{kg} \mathrm{LRH}-\mathrm{A}$, the total milt production was increased 2, 4 and 6 -fold respectively when these treatments were combined with $1 \mathrm{mg}$ PIM. In the second experiment, adult male carp, held in cages in a pond in a natural environment (at a water temperature of $\left.11-14^{\circ} \mathrm{C}\right)$ at the beginning of May, received an intraperitoneal injection of PIM $(1 \mathrm{mg} / \mathrm{kg}$ body weight) and a silicone rubber implant of LRH-A (Des-Gly ${ }^{10}\left[\mathrm{D}-\mathrm{Ala}^{6}\right]$ - LH-RH-ethylamide) at dose of $10 \mu \mathrm{g} / \mathrm{kg}$ body weight simultaneously. Other groups of fish received PIM plus a blank implant. All of the treatments were given at either 6 a.m. or 8 p.m. When given at 6 a.m., the treatment induced a similar rise in plasma GTH $(12-15 \mathrm{ng} / \mathrm{ml}) 24 \mathrm{~h}$ later in the groups treated with PIM and LRH-A implant alone or in combination. When the same treatment was given at $8 \mathrm{p} . \mathrm{m}$., no response was observed 24 or $48 \mathrm{~h}$ later. Spermiation was not stimulated in any of the groups.

\section{INTRODUCTION}

The practices of inducing ovulation and stimulating spermiation in fish rely mainly on the use of fish pituitary homogenates which are expensive to buy, 
not always readily available and of unknown biological activity. The success of this method is quite variable and the average percentage of ovulated female carp in fish farms does not exceed $60 \%$. In order to increase this percentage, scientists over the past few years have sought to find a reliable substitute for pituitary homogenates and to define the optimal conditions of its use.

One candidate, human chorionic gonadotropin (HCG), was found to be potent in only a limited number of species, i.e. Chinese carp (Anon., 1980), sea bass and sea bream (Barnabé and René, 1973; Gordin and Zohar, 1978) and male (Billard, 1977) and female (Stacey et al., 1979a) goldfish. Strangely enough, HCG had no effect on carp; however, it was shown to have side-effects such as atherosclerosis in trout (House et al., 1979) and to raise antibodies in carp (Avtalion and Zohar, personal communication, 1981). Luteinizing hormone-releasing hormone (LH-RH) and some analogues such as LRH-A (Des$\mathrm{Gly}^{10}\left[\mathrm{D}-\mathrm{Ala}^{6}\right] \mathrm{LH}-\mathrm{RH}$-ethylamide, Des-Gly ${ }^{10}\left[\mathrm{D}-\mathrm{Trp}^{6}\right]$ LH-RH-ethylamide and D-Ser (But) ${ }^{6} \mathrm{LH}-\mathrm{RH}$-ethylamide) were found to induce a rise in gonadotropin (GTH) in the blood of various species: goldfish males (Peter, 1980) and females (Sokolowska et al., 1984), common carp females (Weil et al., 1980; Breton et al., 1983) and males (Billard et al., 1983a; Takashima et al., 1984 ), some salmonid females (Crim et al., 1983a; Van Der Kraak et al., 1983) and males (Weil and Crim, 1982, 1983; Weil, unpublished results). In some cases, this rise in GTH was able to induce ovulation; it probably mimicked the normal GTH rise occurring at the time of ovulation, i.e., either a gradual increase over a period of a few days, as in salmonids (Fostier et al., 1978; Jalabert and Breton, 1980), or a marked ovulatory surge, as in goldfish (Breton et al., 1972; Stacey et al., 1979b) and common carp (Fish Reproductive Physiology Research Group and Peptide Hormone Group, 1978).

In addition to these differences in qualitative and quantitative demands between species with regard to ovulation, there also seems to be a strong variation in the ability of the pituitary GTH cell to respond to LRH-A. Some species require only a low level of $\mathrm{LRH}-\mathrm{A}(10 \mu \mathrm{g} / \mathrm{kg})$ to induce ovulation, e.g., Chinese carps (Cooperative Team for Hormonal Application in Pisciculture, 1977; Billard et al., 1982; Rottman and Shireman, 1979) and sea bass (Billard et al., 1984a) while others require higher amounts $(50 \mu \mathrm{g} / \mathrm{kg})$, e.g., goldfish (Chang and Peter, 1983a), tench and carp (Weil et al., 1980; Kouril et al., 1983; Bieniarz et al., unpublished data, 1981-1983). Chang et al. (1983) and Chang and Peter (1983b) showed that GTH-release inhibitory activity was present in goldfish and led to a direct blockage of LRH-A activity. Dopamine was demonstrated to be responsible for this inhibitory activity in goldfish (Chang et al., 1983). The use of pimozide, a dopamine antagonist, greatly potentiated the GTH-releasing activity of LRH-A in goldfish (Chang and Peter, 1983a; Sokolowska et al., 1984), carp (Billard et al., 1983b) and trout (Billard et al., 1984b). Pimozide (PIM) combined with LRH-A allows ovulation in 
these species at doses of less than $50 \mu \mathrm{g} \mathrm{LRH}-\mathrm{A} / \mathrm{kg}$ and offers new perspectives for induced spawning ( $\mathrm{Lin}$ et al., 1986).

The present paper reports two experiments. One was designed to explore the effects of a combination of PIM ( 1 and $10 \mathrm{mg} / \mathrm{kg}$ ) and LRH-A $(0.1,1$ and 10 $\mu \mathrm{g} / \mathrm{kg}$ ), given $6 \mathrm{~h}$ apart, on gonadotropin secretion and spermiation. In a second experiment, the lowest dose of PIM $(1 \mathrm{mg} / \mathrm{kg})$ was used simultaneously with LRH-A $(10 \mu \mathrm{g} / \mathrm{kg})$ included in silicone rubber pellets. This type of administration, previously shown to be potent in the stimulation of GTH secretion in goldfish (Sokolowska, Peter and Billard, unpublished results, 1983 ), was tested here on carp to minimize handling; the LRH-a was included in a pelleted implant to provide delivery over a long period and to sustain the spermiation response (Takashima et al., 1984). As pituitary sensitivity to PIM$\mathrm{LRH}-\mathrm{A}$ may vary over a 24 - $\mathrm{h}$ period, the treatment was given at two different times of day.

\section{MATERIALS AND METHODS}

\section{Effect of different dose combinations of PIM and LRH-A (Experiment 1)}

This experiment was carried out at Jouy-en-Josas. We used male carp from the laboratory stock reared in recycled water and weighing 1-3 kg (see Billard et al., 1983b ). The experiment was carried out in August when the water temperature varied between 15 and $20^{\circ} \mathrm{C}$. The fish, held under a natural photoperiod and starved during the experiment, were divided into 12 lots of 10 males each and given a sequential treatment of two injections. PIM ( 1 and $10 \mathrm{mg} / \mathrm{kg}$ body weight), a gift from Janssen-Lebrun, Paris, was first injected in a vehicle of acidified $\mathrm{NaCl}(6 \mathrm{~g} / \mathrm{l})$ with $200 \mu \mathrm{l}$ acetic acid/l. After $6 \mathrm{~h}$, a second injection of either Des-Gly ${ }^{10}$ [D-Tryp $\left.{ }^{6}\right]$ LH-RH-ethylamide (LRH-A) at $0.1,1$ or 10 $\mu \mathrm{g} / \mathrm{kg}$ body weight, from Hoechst AG, Frankfurt, or the vehicle only $(6 \mathrm{~g} / \mathrm{l}$ of a saline solution of $\mathrm{NaCl}$ ) was given.

The milt was collected in a test-tube by squeezing the abdomen; the milt volume was measured one day before injection and on the day of injection (D0). This was carried out to eliminate any milt that might be stored in the spermiduct. On days 1 and 5 following treatment (D1 and D5), the milt was collected and measured in the same manner; the sperm concentration was estimated by optical density (Takashima et al., 1984). On the same days, blood was taken from the caudal vasculature and the plasma stored at $-20^{\circ} \mathrm{C}$ until the c-GTH assay, according to Breton et al. (1971), was carried out. The results were compared statistically using analysis of variance (ANOVA).

Effect of PIM-LRH-A given at two different times of day (6 a.m. and 8 p.m.) (Experiment 2)

This experiment was carried out at Midlnicky-Krakow, Poland. Male carp, weighing 2-7 kg, aged 4-7 years and originating from the Zator fish farm were 
kept in a small pond $\left(800 \mathrm{~m}^{2}\right)$ at Midlnicky for 1 year prior to the experiment. They were stocked at a loading density of $4000 \mathrm{~kg} / \mathrm{ha}$ and received $10 \mathrm{~kg}$ supplementary food (corn) daily. In April, the water temperature fluctuated between 15 and $18^{\circ} \mathrm{C}$ but dropped to $11-14^{\circ} \mathrm{C}$ at the beginning of May when the experiment was carried out. During the study, the fish were kept in cages in the pond under natural temperatures and cloudy weather (400 lux at the bottom of the cages).

The males were divided into 8 groups of 6 each. One set of 4 groups received the PIM-LRH-A treatment between 6 and 7 a.m. local time ( $1 \mathrm{~h}$ after sunrise) on 4 May and the other 4 groups received the same treatment between 8 and 9 p.m. PIM (a gift from Janssen-Lebrun, Paris) was given intraperitoneally in suspension in an acidified vehicle solution $(0.7 \% \mathrm{NaCl}$ plus $0.1 \%$ sodium metabisulphite) at a dose of $1 \mathrm{mg} / \mathrm{kg}$ body weight ( $1 \mathrm{ml} / \mathrm{kg}$ body weight). LRH-A (Des-Gly ${ }^{10}$ [D-Ala ${ }^{6}$-LH-RH-ethylamide, Beckmann Instrument, batch No. 337734) was included in a silicone rubber pellet (Medical Elastomer 382, Dow Corning) according to the technique described by Lotz and Syllwasschy (1979) and previously used in fish (Crim et al., 1983b; Weil and Crim, 1983; Sokolowska et al., 1984). The 3-cm long pellets, each containing $10 \mu \mathrm{g} \mathrm{LRH}-\mathrm{A} / \mathrm{cm}$, were made and cut according to the weight of the fish in order to give a dose of $10 \mu \mathrm{g} / \mathrm{kg}$ body weight. The pellet was inserted into the body cavity via a $3-\mathrm{mm}$ trocar. The four groups received: (1) PIM plus LRH-A, (2) vehicle plus LRHA, (3) PIM plus blank pellet and (4) vehicle plus blank pellet. Before treatment and 24 and $48 \mathrm{~h}$ afterwards, blood from the caudal vasculature was sampled into a heparinized syringe and the sperm was collected. The plasma was stored at $-20^{\circ} \mathrm{C}$ to await GTH measurement by radioimmunoassay according to Breton et al. (1971). The results were compared statistically by variance analysis (ANOVA).

RESULTS

\section{Experiment 1}

Sperm production was highly variable; on $\mathrm{D} 0$ it was very low (less than 0.55 $\mathrm{ml} / \mathrm{male}$ ) but increased in most of the experimental groups (5-12) on D1 (Table 1). Stimulation was maintained on D5 only in group 12 which received high doses of PIM-LHR-A. The values found for the total volume of milt collected during the experiment (D0+D1+D5) were similar in groups 6,9 and 10 , showing that PIM did not potentialize the effect of $10 \mu \mathrm{g}$ LRH-A. However, at 1 and $10 \mathrm{mg} / \mathrm{kg}$, it did potentialize the effects of LRH-A. Although there was a significant decrease $(P<0.05)$ in the concentration of sperm cells, the stimulation of spermiation resulted in a significant rise in the total number of spermatozoa collected (the data are not shown). The plasma c-GTH concentration measured at D1 increased in comparison with the D0 and D1 controls 
TABLE 1

Effects of various combinations of PIM and LRH-A, given $6 \mathrm{~h}$ apart, on spermiation in carpa

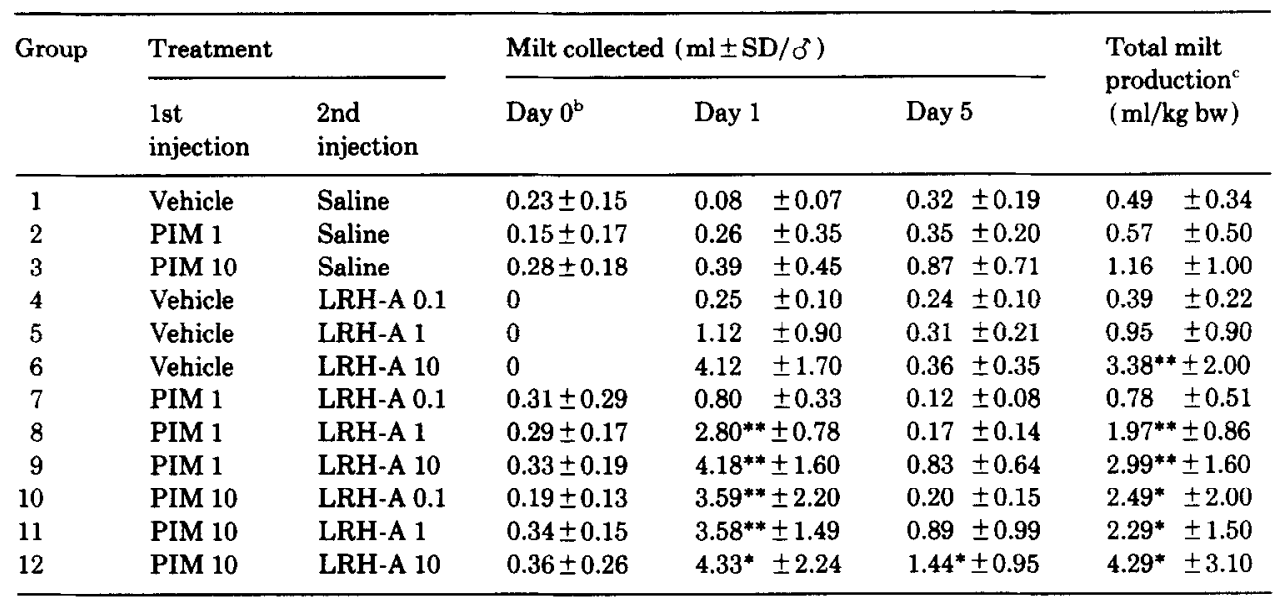

a *: $P<0.05 ;{ }^{* *}: P<0.01$; comparison of milt production at D1 and D5 with that at D0 and of total production with that of group 1.

${ }^{b}$ Milt measured before injection.

cTotal milt production (D0+D1+D5) is given in $\mathrm{ml} / \mathrm{kg}$ body weight (bw).

(C) when the $1 \mathrm{mg}$ PIM plus $1-10 \mu \mathrm{g}$ LRH-A $(P<0.05)$ and $10 \mathrm{mg}$ PIM plus $10 \mu \mathrm{g} \mathrm{LRH}-\mathrm{A}(P<0.001)$ combinations were administered (Fig. 1). By D5, there was no difference between the groups in plasma GTH concentration.

\section{Experiment 2}

In males treated at 6 a.m., there was a significant rise in GTH $24 \mathrm{~h}$ later in all of the groups except the controls (Fig. 2). By $48 \mathrm{~h}$ after the treatment, the plasma GTH concentration was back to the initial pre-treatment level and was comparable in all of the groups. To the contrary, there was no rise in plasma GTH in any group of males treated at 8 p.m. (Fig. 2). The volume of sperm collected was very low $(0.1-0.5 \mathrm{ml} / \mathrm{male})$ before treatment and did not show any change 1 or 2 days later.

\section{DISCUSSION}

The first experiment shows that PIM specifically potentialized the effects of the low doses of LRH-A on the volume of milt and the number of sperm cells collected. Doses as low as $0.1 \mu \mathrm{g}$ LRH-A may be used in combination with a high dose of PIM $(10 \mathrm{mg} / \mathrm{kg})$. Since the long-term effects of these high doses of PIM are not known, it is advisable to use lower doses and increase the amount of LRH-A. The combination of $1 \mathrm{mg}$ PIM plus $1 \mu \mathrm{g} \mathrm{LRH}-\mathrm{A} / \mathrm{kg}$ body weight 


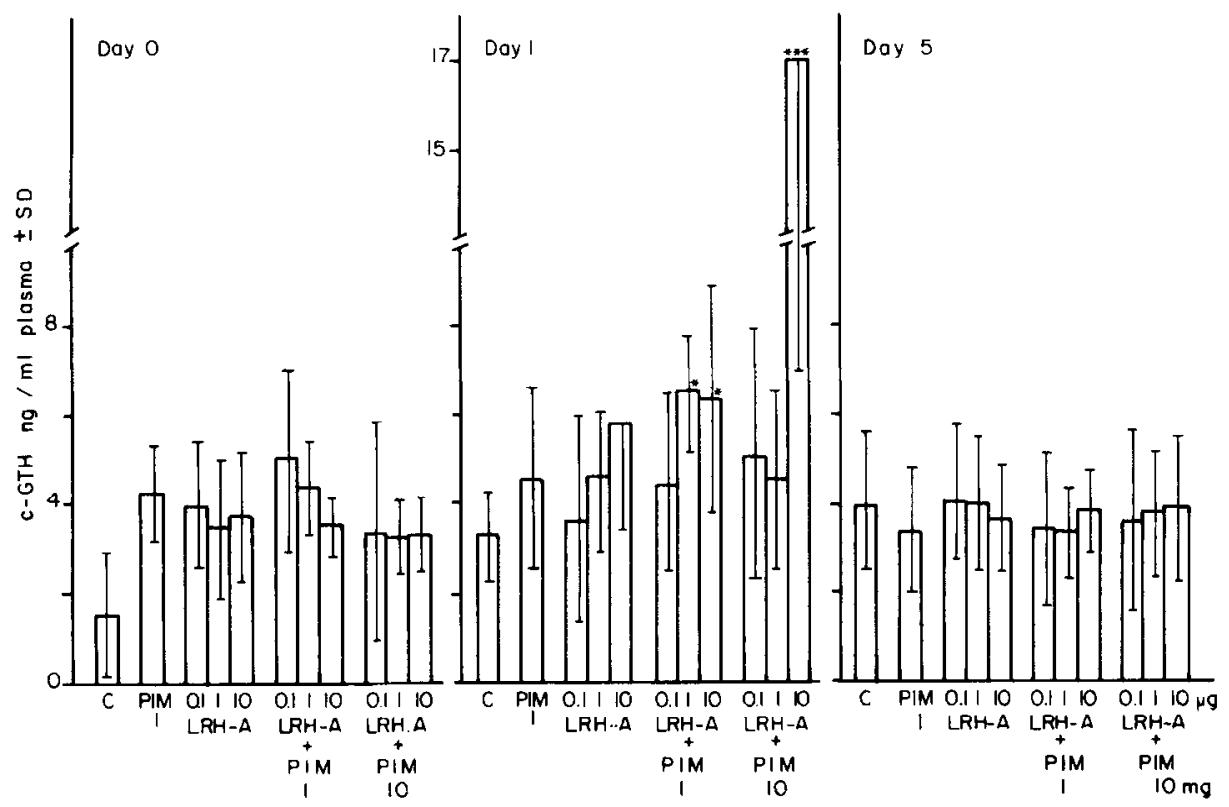

Fig. 1. Change in immunoreactive plasma c-GTH concentration. Injection of saline (C) and 1 and $10 \mathrm{mg} \mathrm{PIM} / \mathrm{kg}$ body weight, given sione or in combination with $0.1,1$ or $10 \mu \mathrm{g} \mathrm{LRH}-\mathrm{A} / \mathrm{kg}$ body weight 6 h later. *: $P<0.05$; ${ }^{* * *}: P<0.001$; comparison with $\mathrm{C}$ on $\mathrm{D} 1$.

might be optimal. Such a combination still maintains a significant rise in GTH $24 \mathrm{~h}$ after the injection. Higher doses of LRH-A $(50 \mu \mathrm{g} / \mathrm{kg})$, whether combined or not with $10 \mathrm{mg}$ PIM did not result in higher milt production (Billard et al., $1983 \mathrm{~b}$ and a respectively).

In the second experiment, LRH-A $(10 \mu \mathrm{g} / \mathrm{kg})$ in pelleted form given at 6 a.m. also induced a rise in GTH that was still visible $24 \mathrm{~h}$ later but, in this case, the lack of potentialization by $1 \mathrm{mg}$ PIM might to due to the fact that it was pelleted, leading to a lower amount of being LRH-A released into the blood. Better responses are reported in the literature. Using higher doses in goldfish ( 25 and $125 \mu \mathrm{g} \mathrm{LRH-A/fish} \mathrm{),} \mathrm{Sokolowska} \mathrm{et} \mathrm{al.} \mathrm{(1984)} \mathrm{stimulated} \mathrm{GTH} \mathrm{secre-}$ tion for 7-8 days. In land-locked male Atlantic salmon, Weil and Crim (1983) observed an elevation of plasma GTH for at least 12 days with pelleted LRHA at a dose of $270-1600 \mu \mathrm{g} / \mathrm{kg}$ body weight. If the low response observed in the present experiment was due to the low dose of LRH-A introduced by way of a pellet, the I.RH-A concentration in the pellet could be increased but the treatment would cost mo:e and, thus, would not be feasible in practice.

The non-stimulation of spermiation in this experiment was probably due to the low water temperature $\left(11-14^{\circ} \mathrm{C}\right)$. In a previous study carried out at $10-13^{\circ} \mathrm{C}$, there was no spermiation response to LH-RH or LRH-A (10 and 50 $\mu \mathrm{g} / \mathrm{kg}$ body weight) $24 \mathrm{~h}$ after treatment (Billard et al., 1983a). Repeated daily 


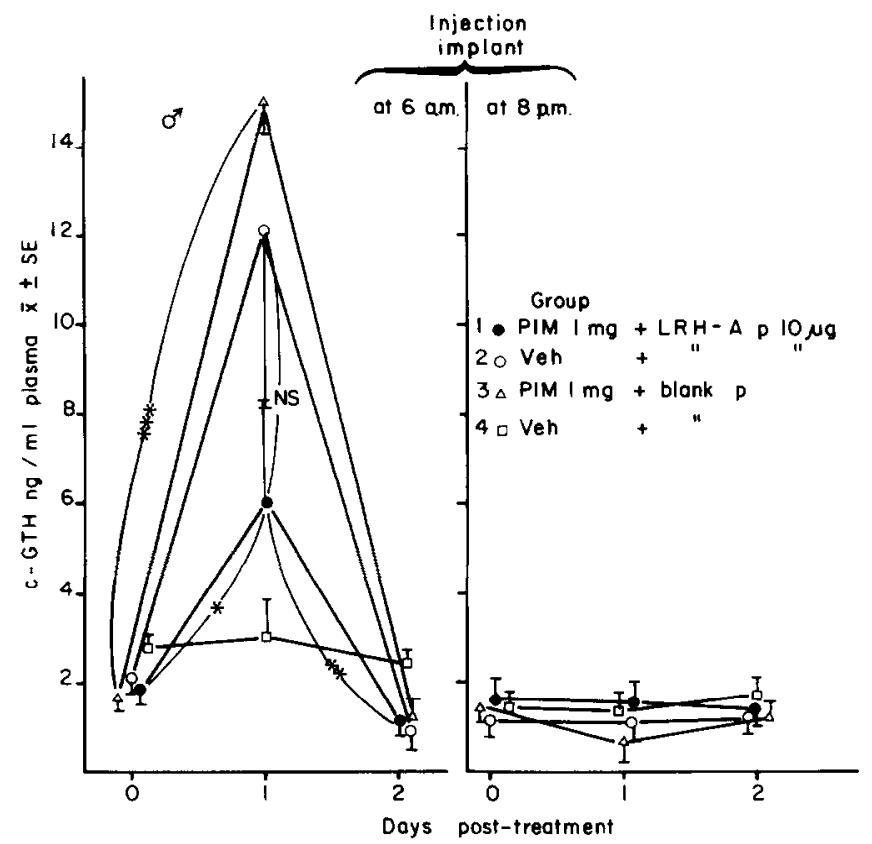

Fig. 2. Plasma c-GTH changes in male carp following simultaneous intraperitoneal injection of PIM or vehicle (veh) and implant of an LRH-A pellet (p) given at 6 a.m. or 8 p.m. ${ }^{*}: P<0.05$; ${ }^{* *}: P<0.01 ;{ }^{* * *}: P<0.001$; NS: non-significant.

injections had to be given in order to obtain a response, which was only seen after 4-5 days. However, it should be pointed out that the level of GTH recorded at D1 was the same in the two present experiments carried out at two different temperatures. Temperature seems to have an effect on the testis.

The striking difference in response, depending on whether the treatment was given in the morning or the evening, raises the problem of a change in pituitary responsiveness to gonadotropin releasing hormone $(\mathrm{GnRH})$ over a $24-\mathrm{h}$ period. The problem has not been thoroughly investigated in fish so far. In a study on the effect of LH-RH and its analogues on GTH secretion in male goldfish, Peter (1980) observed that repeated injection of LH-RH or LRH-A did not give the same response when injected 12 or $24 \mathrm{~h}$ apart. These differences might be due to a change in the responsiveness of the pituitary to exogenous LRH-A during the day. Similarly, it has been shown in carp that the response of the ovary (oocyte maturation) to exogenous pituitary homogenate injection varies over a 24 -h period (Bieniarz et al., unpublished results). This has also been related to nycthemeral changes in the rate of hormone secretion in female carp (Bieniarz et al., 1984). Temporal variation in the responsiveness of the ovary to gonadotropin has been demonstrated in goldfish (Peter et al., 1982) which show a daily cycle in the serum GTH level (Hontela and Peter, $1978,1980)$. Daily changes in the pattern of hormone secretion and in the 
sensitivity of the target organ to hormones require more investigation and must be taken into account when seeking to improve the efficiency of the hypophysation technique.

\section{ACKNOWLEDGEMENTS}

This work was supported by an international grant from I.N.R.A. and a PR 4 grant from the Inland Fisheries Institute to K. Bieniarz.

\section{REFERENCES}

Anon., 1980. Pond fish culture in China. Pearl River Fisheries Research, Institute Guangzhou, China.

Barnabé, G. and René, F., 1973. Reproduction contrôlée et production d'alevins chez la dorade Sparus auratus Linné 1758. C.R. Acad. Sci., 276: 1621-1624.

Bieniarz, K., Sokolowska, M., Fostier, A. and Epler, P., 1984. Daily changes in blood serum levels of $17 \beta$-estradiol and 11-ketotestosterone in the adult mature carp Cyprinus carpio. Chronobiologia, 2: 93-101.

Billard, R., 1977. Effect of various hormones on sperm release in the hypophysectomized goldfish. IRCS, 5: 188.

Billard, R., Marcel, J., Matei, D. and Rusu, C., 1982. Induction de l'ovulation par un analogue du LH-RH chez Hypophthalmichthys molitrix (poisson téléosteen) placé dans diverses conditions d'environnement. Bul. Cercet. Piscic., 4: 29-31.

Billard, R., Choisis, J. P. and Reinaud, P., 1983a. Stimulation of spermiation in carp in response to LH-RH and D-Ala ${ }^{6}$-LH-RH ethylamide. Aquaculture, 35: 173-176.

Billard, R., Alagarswami, K., Peter, R. E. and Breton, B., 1983b. Potentialisation par le pimozide des effects du LHRH-A sur la sécrétion gonadotrope hypophysaire, l'ovulation et la spermiation chez la carpe commune (Cyprinus carpio). C.R. Acad. Sci., 296: 181-184.

Billard, R., Weil, C. and Barnabé, G., 1984a. Induction de l'ovulation et stimulation de la spermiation par le LHRH ou un analogue du LHRH associé ou non au pimozide chez quelques espèces de possoins téléstéens. Actes Colloq. CNEXO, 1: 321-322.

Billard, R., Reinaud, P., Hollobecq, M. G. and Breton, B., 1984b. Advancement and synchronisation of spawning in Salmo gairdneri and S. trutta following administration of LRH-A combined or not with pimozide. Aquaculture, 43: 57-66.

Breton, B., Kann, G., Burzawa-Gerard, E. and Billard, R., 1971. Dosage radioimmunologique d'une hormone gonadotrope de carpe Cyprinus carpio. C.R. Acad. Sci., 272: 1515-1517.

Breton, B., Billard, R., Jalabert, B. and Kann, G., 1972. Dosage radioimmunologique des gonadotropines plasmatiques chez Carassius auratus, au cours du nycthémère et pendant l'ovulation. Gen. Comp. Endocrinol., 18: 463-468.

Breton, B., Jalabert, B., Bieniarz, K., Sokolowska, M. and Epler, P., 1983. Effects of synthetic LH-RH and analog on plasma gonadotropin levels and maturational response to $17 \alpha$-hydroxy20 $\beta$-dihydroprogesterone. Aquaculture, 32: 105-114.

Chang, J. P. and Peter, R. E., 1983a. Effects of pimozide and des Gly $^{10}$, [D-Ala ${ }^{6}$ luteinizing hormone-releasing hormone ethylamide on serum gonadotropin concentrations, germinal vesicle migration and ovulation in female goldfish Carassius auratus. Gen. Comp. Endocrinol., 52: 30-37.

Chang, J. P. and Peter, R. E., 1983b. Effects of dopamine on gonadotropin release in female goldfish, Carassius auratus. Neuroendocrinology, 36: 351-357. 
Chang, J. P., Cook, A. F. and Peter, R. E., 1983. Influence of catecholamines on gonadotropin secretion in goldfish, Carassius auratus. Gen. Comp. Endocrinol., 49: 22-31.

Cooperative Team for Hormonal Application in Pisciculture, 1977. A new highly effective ovulating agent for fish reproduction; practical application of LH-RH analogue for the induction of spawning of farm fishes. Sci. Sin., 20: 469-474.

Crim, L. W., Evans, D. M. and Vickery, B. H., 1983a. Manipulation of the seasonal reproductive cycle of the landlocked salmon (Salmo salar) by LHRH analogues administered at various stages of gonadal development. Can. J. Fish. Aquat. Sci., 40: 61-67.

Crim, L. W., Sutterlin, A. M., Evans, D. M. and Weil, C., 1983b. Accelerated ovulation by pelleted LHRH analogue treatment of spring-spawning rainbow trout (Salmo gairdneri) held at low temperature. Aquaculture, 35: 299-307.

Fish Reproductive Physiology Research Group and Peptide Hormone Group, 1978. Radioimmunoassay on serum gonadotropin of carp (Cyprinus carpio L.). Acta Biochim. Biophys. Sin., 10: 399-407.

Fostier, A., Weil, C., Terqui, M., Breton, B. and Jalabert, B., 1978. Plasma estradiol-17 $\beta$ and gonadotropin during ovulation in rainbow trout (Salmo gairdneri R.) Ann. Biol. Anim. Biochem. Biophys., 18: 929-936.

Gordin, H. and Zohar, Y., 1978. Induced spawning of Sparus aurata by means of hormonal treatment. Ann. Biol. Anim. Biochem. Biophys., 18: 985-990.

Hontela, A. and Peter, R. E., 1978. Daily cycles in serum gonadotropin levels in the goldfish: effects of photoperiod, temperature, and sexual condition. Can. J. Zool., 56: 2430-2442.

Hontela, H. and Peter. R. E., 1980. Effects of pinealectomy, blinding and sexual condition on serum gonadotropin levels in the goldfish. Gen. Comp. Endocrinol., 40: 168-179.

House, E. W., Dornauer, R. J. and Van Lenten, B. J., 1979. Production of coronary arteriosclerosis with sex hormones and human chorionic gonadotropin (HCG) in juvenile steelhead and rainbow trout, Salmo gairdneri. Atherosclerosis, 34: 197-206.

Jalabert, B. and Breton, B., 1980. Evolution de la gonadotropine plasmatique t-GTH après l'ovulation chez la truite arc-en-ciel (Salmo gairdneri R.), et influence de la rétention des ovules. C.R. Acad. Sci. Ser. D., 290: 799-801.

Kouril, J., Barth, T., Hamackova, J., Slaninova, J., Servitova, L., Machacek, J. and Flegel, M., 1983. Application LH-RH and its analog for reaching ovulation in female tench, grass carp, carp and sheat fish. Bul. VURH Vodnany, 2: 3-16.

Lin, H. R., Liang, J. Y., Peng, C., Li, G. Y., Lu, L. Z., Zhou, X. J., Van der Kraak, G. and Peter, R. E., 1986. The effects of LHRH analogue and drugs which block the effects of dopamine on gonadotropin secretion and ovulation in fish cultured in China. In: R. Billard and J. Marcel (Editors), Aquaculture of Cyprinids. INRA Publ., pp. 139-150.

Lotz, W. and Syllwasschy, B., 1979. Release of oligopeptides from silicone rubber implants in rats over periods exceeding ten days. J. Pharm. Pharmacol., 31:649-650.

Peter, R. E., 1980. Serum gonadotropin levels in mature male goldfish in response to luteinizing hormone-releasing hormone (LH-RH) and des-Gly ${ }^{10}-\left[\right.$ D-Ala $\left.{ }^{6}\right]-\mathrm{LH}-\mathrm{RH}$ ethylamide. Can. J. Zool., 58: 1100-1104.

Peter, R. E., Paulencu, C. R. and Breton, B., 1982. Temporal responsiveness of the ovary of goldfish to gonadotropin. J. Interdiscip. Cycle Res., 13: 229-239.

Rottman, R. W. and Shireman, J. V., 1979. Tank spawning of grass carp. Aquaculture, 17: 257-261.

Sokolowska, M., Peter, R. E., Nahorniak, C. S., Pan, C. H., Chang, J. P., Crim, L. W. and Crim, C., 1984. Induction of ovulation in goldfish, Carassius auratus, by pimozide and analogues of LH-RH. Aquaculture, 36: 71-83.

Stacey, N. E., Cook, A. F. and Peter, R. E., 1979a. Spontaneous and gonadotropin induced ovulation in the goldfish, Carassius auratus: effects of external factors. J. Fish Biol., 15: 349-361.

Stacey, N. E., Cook, A. F. and Peter, R. E., 1979b. Ovulatory surge of gonadotropin in the goldfish Carassius auratus. Gen. Comp. Endocrinol., 37: 246-249. 
Takashima, F., Weil, C., Billard, R., Crim, L. W. and Fostier, A., 1984. Stimulation of spermiation by LHRH analogue in carp. Bull. Jn. Soc. Sci. Fish., 50: 1323-1329.

Van Der Kraak, G. L., Lin, H. R., Donaldson, E. M., Dye, H. M. and Hunter, G. A., 1983. Effects of LH-RH and des-Gly ${ }^{10}$ [D-Ala $\left.{ }^{6}\right]$ LH-RH ethylamide on plasma gonadotropin levels and oocyte maturation in adult female coho salmon (Oncorhynchus kisutch). Gen. Comp. Endocrinol., 49: 470-476.

Weil, C. and Crim, L. W., 1982. A study of methods of administering LHRH analogue: advancement of spermiation in the landlocked salmon (Salmo salar). In: C. J. J. Richter and H. J. Th. Goos (Compilers), Reproductive Physiology in Fish. PUDOC, Wageningen, p. 26.

Weil, C. and Crim, L. W., 1983. Administration of LHRH analogues in various ways: effect on the advancement of spermiation on prespawning landlocked salmon Salmo salar. Aquaculture, 35: 103-115.

Weil, C., Fostier, A., Horvath, L., Marlot, S. and Berscenyi, M., 1980. Profiles of plasma gonadotropin and $17 \beta$-estradiol in the common carp Cyprinus carpio $L$. as related to spawning induced by hypophysation or LH-RH treatment. Reprod. Nutr. Dév., 20: 1041-1050. 